\title{
Cesarán las palabras : la lengua de los diálogos en un texto
}

\section{cuatrocentista}

\section{Lola Pons Rodríguez}

\section{Resumen}

Resumen En este artículo se describen los principales rasgos lingüísticos de las escenas dialógicas insertas en la obra castellana Virtuosas e claras mugeres (1446) de Álvaro de Luna. Se atiende a cuestiones sintácticas y discursivas como los

verba dicendi, las relaciones entre la cita y el contexto de reproducción y la organización interna de los enunciados; se ofrece, a partir de los parámetros de inmediatez y distancia comunicativa, una caracterización del tipo de interacción que se refleja en ellos. El trabajo parte de una reflexión sobre la dificultad metodológica de buscar en los diálogos literarios muestras históricas de la oralidad.

\section{Résumé}

Résumé

Dans cet article sont décrits les principaux traits linguistiques des scènes dialogiques comprises dans l'oeuvre castillane Virtuosas e claras mugeres (1446) d'Álvaro de Luna. Y sont analysées des questions syntaxiques et discursives comme les verba dicendi,

les rapports entre la citation et son contexte de reproduction ainsi que l'organisation interne des énoncés; on offre à partir des paramètres de l'immédiat communicatif et de la distance communicative une caractérisation du type d'interaction reflétée dans ces énoncés. Le travail s'appuie sur une réflexion à propos de la difficulté méthodologique de chercher dans les dialogues littéraires des marques historiques d'oralité.

\section{Citer ce document / Cite this document :}

Pons Rodríguez Lola. Cesarán las palabras : la lengua de los diálogos en un texto cuatrocentista. In: Cahiers d'études hispaniques médiévales. N³0, 2007. pp. 289-320.

doi : $10.3406 /$ cehm.2007.1811

http://www.persee.fr/doc/cehm_0396-9045_2007_num_30_1_1811

Document généré le 05/01/2016 


\title{
Cesarán las palabras : la lengua de los diálogos en un texto cuatrocentista
}

\author{
Lola PONS RODRÍGUEZ
}

Universidad de Sevilla

\begin{abstract}
RESUMEN
En este artículo se describen los principales rasgos lingüísticos de las escenas dialógicas insertas en la obra castellana Virtuosas e claras mugeres (1446) de Álvaro de Luna. Se atiende a cuestiones sintácticas y discursivas como los verba dicendi, las relaciones entre la cita y el contexto de reproducción y la organización interna de los enunciados; se ofrece, a partir de los parámetros de inmediatez y distancia comunicativa, una caracterización del tipo de interacción que se refleja en ellos. El trabajo parte de una reflexión sobre la dificultad metodológica de buscar en los diálogos literarios muestras históricas de la oralidad.

RÉSUMÉ

Dans cet article sont décrits les principaux traits linguistiques des scènes dialogiques comprises dans l'cuvre castillane Virtuosas e claras mugeres (1446) d'Álvaro de Luna. $\Upsilon$ sont analy sées des questions syntaxiques et discursives comme les verba dicendi, les rapports entre la citation et son contexte de reproduction ainsi que l'organisation interne des énoncés; on offre à partir des paramètres de l'immédiat communicatif et de la distance communicative une caractérisation du type d'interaction reflétée dans ces énoncés. Le travail s'appuie sur une réflexion à propos de la difficulté méthodologique de chercher dans les dialogues littéraires des marques historiques d'oralité.
\end{abstract}

0 . Una de las líneas de trabajo con mayor éxito dentro de las actuales investigaciones sobre sintaxis diacrónica y discurso histórico en español es, sin duda alguna, la búsqueda de posibles rasgos de la oralidad en los textos del español antiguo. El interés por estos elementos se ubica dentro de un ámbito de estudios más amplio: el de la variación, un fenómeno que - particularmente en el terreno de la Sintaxis - está recibiendo una

$$
\text { CEHM, n } 30,2007, \text { p. 289-320 }
$$


significativa atención crítica en la Lingüística Histórica española de los últimos años ${ }^{1}$. Las indagaciones sobre diacronía y oralidad parten, con todo, de una constricción metodológica en su base, y es la imposibilidad empírica de reconstruir la historia de la lengua oral a partir de textos:

La actitud de los historiadores de la lengua al discutir teóricamente la oralidad y al imbricarla en la evolución idiomática puede ir del desconcierto al solapamiento del problema o a la búsqueda desesperada de una solución que se siente imposible. Conscientes de que el cambio lingǘstico se da en el hablar, sólo tienen, sin embargo, a su disposición un sector reducido de la producción lingüística, la que se fija en la escritura (y aún ésta suele llegarles incompleta), a la que han de recurrir para encontrar en ella las huellas de lo hablado, o mejor dicho, del modo en que se habló en tiempos pasados [...] paradójicamente, lo que la Historia de la lengua hace normalmente es historia de la lengua general a través de la lengua de la escritura: en suma, el historiador de la lengua hace historia de la lengua escrita como si ésta fuera representante sin más de la lengua total ${ }^{2}$.

En gran parte de los trabajos sobre lengua hablada en diacronía, no se habla propiamente tanto de oralidad como de inmediatez comunicativa, término que remite al aparato teórico de la nueva lingüística de las variedades alemana ${ }^{3}$ y que concibe como dos planos distintos el medio o canal en que se realiza la comunicación — donde se efectúa una separación dicotómica entre un canal gráfico o un canal fónico - y la concepción o forma lingüística en que se configura la comunicación — donde cabe separar en un eje gradual lo hablado y lo escrito, polos que se pueden hacer corresponder con los parámetros variacionales de inmediatez comunicativa y distancia comunicativa:

Tenemos que buscar en textos, es decir, en manifestaciones gráficas - y no hay otra solución -, evidencias de las formas y variantes lingüísticas que normalmente no se escriben, puesto que se emplean sólo en el dominio de la inmediatez comunicativa $^{4}$.

1. Vid. Álvaro S. Octavio De TOledo y Huerta, «Varia lectio y variación morfosintáctica: el caso del Crotalón», in: L. PONS RODRíGUEZ (ed.): Historia de la lengua y crítica textual, Madrid-Frankfurt: Vervuert-Iberoamericana, 2006, nota 1.

2. Rafael Cano AguilaR, «Sintaxis histórica, discurso oral y discurso escrito», in: José Jesús DE Bustos Tovar (ed.), Textualización y oralidad, Madrid: Instituto universitario Menéndez Pidal - Visor Libros, 2003, p. 27-48.

3. Peter Koch, Wulf OesterReicher, Lengua hablada en la Romania: español, francés, italiano. Madrid: Gredos (Biblioteca románica hispánica), 2006, trad. esp. de Araceli LóPEz SERENA de Gesprochene Sprache in der Romania: Französisch, Italienisch, Spanisch, Tubinga: Max Niemeyer (Romanistische Arbeitshefte, 31), 1990.

4. Wulf OESTERREICHER, «Lo hablado en lo escrito. Reflexiones metodológicas y aproximación a una tipología», in: Thomas KOTSCHI et al. (ed.), El español hablado y la cultura oral en España e Hispanoamérica, Madrid-Frankfurt: Vervuert-Iberoamericana, 1996, p. 318-337, p. 323. 
El rastreo de los rasgos de la oralidad en diacronía se ha llevado a cabo tanto en aquellos textos donde la expresión del discurso referido puede estar filtrando rasgos lingüísticos propios de una oralidad real, efectivamente producida, como en obras donde de manera ficcional parece estar recreándose lo hablado, es decir, en obras donde se produce el fenómeno conocido como mímesis de la oralidad.

$\mathrm{Al}$ primer ámbito pertenecen trabajos como los de Eberenz y Eberenz y De la Torre sobre los fragmentos de discurso reproducido en las actas de la Inquisición, el estudio de Wesch sobre la oralidad en pareceres bajomedievales, los análisis de los documentos emitidos por semicultos - campo en el que destaca la interesante documentación epistolar y memorial surgida de la migración a Indias ${ }^{5}$ - y otros escritos como los epistolarios amorosos $^{6}$.

La búsqueda de estos fenómenos de impronta oral en textos literarios es especialmente complicada, pues la recreación de escenas habladas, de interacciones, está inevitablemente «adulterada» por un revestimiento de estilización literaria. La forzosa presencia de valores paramétricos de la distancia comunicativa que se da en todo discurso llevado al plano gráfico se subraya en estos casos, en los que, más que recrear la oralidad real, los autores se sienten compelidos a escenificar una oralidad literaria, que limita la introducción o a la adaptación de elementos conversacionales. En este segundo ámbito contamos con trabajos que estudian la formas de enunciación en textos primitivos ${ }^{7}$, en

5. Rolf EBEREnZ, «Huellas de la oralidad en textos de los siglos XV y XVI», in: José Jesús DE Bustos TOVAR, ibid., p. 63-83; Rolf EBEREnZ, Mariela DE LA TORRE, Conversaciones estrechamente vigiladas: interacción coloquial y español oral en las actas inquisitoriales de los siglos XV a XVII, Zaragoza: Libros Pórtico - Hispania Helvetica, 14, 2003; Andreas WESCH, «Cambio medial y huellas de lo oral en Pareceres protocolizados de los siglos XV y XVI», in: José Jesús DE BUSTOS TOVAR, José Luis GIRÓn ALCONCHEL (ed.), Actas del VI Congreso internacional de historia de la lengua española: Madrid, 29 de septiembre - 3 de octubre 2003, vol. 3, 2006, p. 2949-2962; Rafael CANO AGUILAR, «Lenguaje "espontáneo" y retórica epistolar en cartas de emigrantes españoles a Indias», in: Wulf OESTERREICHER et al. (ed.), Competencia escrita, tradiciones discursivas y variedades lingüísticas. Aspectos del español europeo y americano en los siglos XVI y XVII, Tubinga: Gunter Narr, 1998, p. 374-404; Konstanze JUNGBLUTH, «El carácter de los textos semiorales y el junctor que», in: W. OESTERREICHER et al., ibid., p. 339-358; W. OESTERREICHER, ibid.; Roland SCHMIDT-RIESE, Relatando México. Cinco textos del período fundacional de la colonia en tierra firme. Madrid-Frankfurt: Vervuert-Iberoamericana (Textos y documentos españoles y americanos), vol. 3, 2003; Eva STOLL, La memoria de Juan Ruiz de Arce. Conquista del Perú, saberes secretos de caballería y defensa del mayorazgo. Madrid-Frankfurt: Iberoamericana (Textos y documentos españoles y americanos), vol. 2, 2002.

6. Carmela PÉREZ-SALAZAR, «Manifestaciones del habla coloquial en un tipo de escrito: las cartas de amor (siglos XVI-XVIII)», in: M T. ECHENIQUE ELIZONDO et al. (ed.), Actas del V Congreso internacional de historia de la lengua española, Madrid: Gredos, 2002, vol. I, p. 877-890.

7. José Jesús DE Bustos TOVAR, «Algunos aspectos de las formas de enunciación en textos medievales», in: M. ARIZA et al. (ed.): Actas del II Congreso internacional de historia de la lengua española. Madrid: Pabellón de España, 1992, p. 569-577; $i d$., «L'oralité dans les anciens textes castillans», in: Maria SELIG et al. (ed.), Le passage à l'écrit des langues romanes, Tubinga: Gunter Narr, 
textos líricos ${ }^{8}$, la representación de lo hablado en fragmentos dialógicos cervantinos $^{9}$, en los pasajes dialógicos de un corpus de obras medievales castellanas ${ }^{10}$, en el grupo de obras canónicamente consagradas como representativas de la oralidad en español antiguo ${ }^{11}$ o en textos del Renacimiento español pertenecientes propiamente al género expositivo del «diálogo» ${ }^{12}$. La atención concedida a las formas de diálogo en textos históricos ${ }^{13}$ nos ha permitido conocer un amplio repertorio de recursos de modalización utilizados en diacronía ${ }^{14}$, si bien se admite que el hallazgo de elementos de lo hablado en tales fragmentos textuales quedará más en el dominio de la hipótesis que de lo comprobado. Ello se

1993, p. 247-262; id., «De la oralidad a la escritura», in: Actas del I Simposio sobre análisis del discurso. Almería: Universidad, 1995, p. 11-28; id., «La construcción del diálogo en los entremeses cervantinos», in: En torno al teatro del Siglo de oro, Almería: Instituto de Estudios Almerienses, 1996, p. 275-290; id., «Algunos tipos de diálogo en el español del siglo XVI», in: José Jesús DE Bustos TOVAR et al. (ed.), Lengua, discurso, texto, I Simposio internacional de análisis del discurso. Madrid: Visor, 2000, p. 1515-1530; $i d$., «De la oralidad a la escritura en la transición de la Edad Media al Renacimiento: la textualización del diálogo conversacional», El criticón, 81-82, 2001, p. 191-206.

8. Silvia IGLesias Recuero, Oralidad, diálogo y contexto en la lírica tradicional, Madrid: Visor Libros, 2002.

9. J. J. DE Bustos TOVAR, «Elementos conversacionales en el diálogo renacentista», in: W. OESTERREICHER et al. (ed.), loc. cit, p. 385-319; Antonio NARBONA JimÉNEZ, «Sintaxis de lo oral y sintaxis de la escritura de lo oral en los diálogos del Quïjote», ponencia leída en el Seminario de historia de la lengua española «Lengua y lingüística en la época del Quijote» (Soria, Fundación Duques de Soria, 5 al 9 de julio de 2005).

10. Elena LEAL ABAD, La sintaxis del diálogo en la Edad Media castellana, tesis doctoral inédita, dirigida por Rafael CANO AGUILAR (Universidad de Sevilla, 2005).

11. J.J. DE Bustos TOVAR, «De la oralidad a la escritura en la transición de la Edad Media al Renacimiento: la textualización del diálogo conversacional», El criticón, 81-82, 2001, p. 191-206. Ana VIAN HERRERO, «La ficción conversacional en el diálogo renacentista», Edad de oro, 7,1988, p. 173-186.

12. J.J. De Bustos Tovar et al. (ed.), Lengua, discurso, texto, I Simposio internacional de análisis del discurso, op. cit.; S. IGLESIAS RECUERO, Oralidad, diálogo y contexto en la lírica tradicional, op. cit.; Ana VIAN HERRERO, «La ficción conversacional en el diálogo renacentista», Edad de oro, 7, 1988, p. 173-186.

13. Para otras lenguas, ver Andreas Jucker, Gerd FrITZ, Franz LEBSANT, «Historical Dialogue Analysis: Roots and Traditions in the Study of the Romance Languages, German and English», in: Historical Dialogue Analysis, Amsterdam-Philadelphia: John Benjamins, 1999, p. 133. Vid. también al respecto algunas reflexiones en Lola PONS RODRÍGUEZ, «Reseña a Teresa Langle de Paz (2004): ¿Cuerpo o intelecto? Una respuesta femenina al debate sobre la mujer en la España del siglo XVII. Málaga: Universidad de Málaga «Philologia Hispalensis, XVIII (2004), p. 251-255. Es recomendable también el trabajo de Michael ZAPPALA sobre el uso de la voz diálogo en los siglos XV y XVI y el acercamiento que a ella hacen prehumanistas y humanistas: «Fablemos latino: diálogo, Latin Roots and Vernacular Landscape in Fifteenth Century Castille», Ibero romania, 29,1989, p. 43-64.

14. Acerca de la modalización como fenómeno enunciativo - discursivo que busca las manifestaciones de la subjetividad lingüística, resulta muy útil el panorama que brinda: Alicia LÓPEZ LÓPEZ «Hacia un estudio de la subjetividad lingüística en la historia de la lengua», in: José Jesús De Bustos Tovar, José Luis GIRÓn AlCONCHEL (ed.), Actas del VI Congreso internacional de historia de la lengua española, Madrid: Arco-Libros, 2006: p. 2797-2806. 
acentúa en los textos de «género diálogo» que se multiplican en el XVI, en los que se textualiza una interacción ${ }^{15}$ entre dos o más personas (de las cuales una de ellas suele poseer el papel de maestro, lo que condiciona notablemente la toma de turnos) que imita una disputa dialéctica con una fuerte presencia de elementos argumentativos, pero apenas deja pasar rasgos del diálogo conversacional tales como la falta de planificación o la posibilidad de digresión ${ }^{16}$.

En este trabajo se presentan y describen los principales rasgos lingüísticos de las escenas dialógicas que se hallan en la obra de don Álvaro de Luna Virtuosas e claras mugeres (1446). Escrita para defender la virtud de la mujer en una época en que arrecia en la literatura el debate filoginia/misoginia, esta obra recopila las biografías de más de cien mujeres virtuosas de tres épocas: la de la ley divinal, donde se incluye a mujeres bíblicas como Esther, Sara, Judith, Susana...; la de la ley natural, que agrupa a mujeres de la tradición grecorromana como Casandra, Lucrecia, Tanaquil, Sempronia... o figuras divinas como Ceres, Diana, Minerva...; y, por último, la de la ley de gracia, donde figuran diversos relatos de mujeres santas transmitidas por la tradición hagiográfica románica. Partiendo de los antecedentes bibliográficos ya comentados, y conociendo el tipo de obra ante la cual nos situamos, en este trabajo no se pretenderá tanto buscar rasgos de la inmediatez comunicativa en los enunciados dialogados de Virtuosas e claras mugeres como, más bien, describir y caracterizar los rasgos del reflejo del discurso referido en lo escrito, reflejo que obliga al uso de una serie de procedimientos sintácticos que vale la pena detenerse a analizar.

En primer lugar, se expondrá una caracterización de los tipos de enunciados de discurso referido que encontramos en el tratado de don Álvaro y se precisará en qué punto del continuo concepcional distancia/

15. No identificable con una conversación. Para Carmen BOBES NAVES, «El diálogo es un proceso de interacción en el que la actividad de los interlocutores es complementaria para la creación de un sentido único a lo largo del proceso y mientras éste dura. La convergencia de las intervenciones hacia la unidad de sentido es el rasgo que diferencia al diálogo de otros procesos interactivos, como puede ser la conversación, que es abierta en cuanto al sentido», vid. Carmen Bobes Naves, El diálogo. Estudio pragmático, lingüístico y literario. Madrid: Gredos, 1992, p. 38. Vid. al respecto de la caracterización que luego desarrolla BOBES NAVES sobre los ingredientes del diálogo la crítica de J. J. Bustos TOVAR, «De la oralidad...».

16. Sobre los distintos tipos de diálogo en español en el siglo XVI, vid. J. J. BusTOS TOVAR, «Algunos tipos de diálogo...» y Jesús GÓMEZ, El diálogo en el Renacimiento español, Madrid: Cátedra, 1988. Para los estudios sobre diálogo, la importancia del siglo XVI radica en que a partir de ese momento se desarrollan en grado creciente (sobre todo a partir de 1525) los textos escritos por completo en forma dialógica, los llamados diálogos discursivos. Con todo, hay que recordar la existencia de antecedentes cuatrocentistas de obras en género dialogado, como el Diálogo $e$ razonamiento en la muerte del marqués de Santillana $\left({ }_{\llcorner} 1464\right.$ ? $)$ de PERO DÍEZ DE TOLEDO y el Libro de vida beata de Juan de Lucena (1463), ambos carentes aún de un estudio lingüístico. Los diálogos de controversia como la Razón de amor, la Disputa entre un cristiano y un judío... son más antiguos y no pueden, por razones diversas, adscribirse a este género del diálogo discursivo. 
inmediatez comunicativa se pueden ubicar los diálogos que se encuentran en la obra $(\S 1)$; sigue un intento de caracterización exhaustiva de la sintaxis de tales diálogos atendiendo a aspectos como su contexto de reproducción y los tipos de verbos introductores utilizados (\$2) y, por último, se considera el tipo de enunciados que se emplean dentro de estas escenas, el contenido del discurso directo en el que se sondeará si hubo algún intento por parte del autor de reflejar rasgos de lo hablado (§3).

1. Los enunciados de diálogo literario suponen la reproducción del discurso ajeno en el propio, es decir, explicitan la deuda contraída con la enunciación ajena, muestran la heterogeneidad ${ }^{17}$. No son, naturalmente, los únicos tipos de enunciado en que hay una mostración explícita de esa heterogeneidad discursiva. En frases de Virtuosas e claras mugeres no pertenecientes a diálogo como:

(1) Muy público es por actoridad de los nuestros mayores que la noble virgen Camila fue fija de Metabo, rey de los volscos muy viejo, e de Casmila su muger, la qual dizen que quando nació fue causa que su madre morió (fol. $143 \mathrm{r}^{\circ}-\mathrm{v}^{\circ}$ );

(2) El dicho profeta Daniel a grandes bozes dixo que aquella muerte se fazía contra justicia e que él non era en ella. Estonce el pueblo le preguntaron qué cosa era aquella que dizía, él les dixo: - Esta muger es condepnada a muerte falsamente contra toda verdad (fol. $\left.43 \mathrm{v}^{\mathrm{o}}\right)^{18}$.

hay también, efectivamente, procedimientos de introducción del discurso ajeno en el propio, manifestación de discurso referido: en (1) vemos cómo don Álvaro utiliza evidenciales citativos para incorporar una instancia enunciativa a su texto a la que se cede la responsabilidad de la enunciación (muy público es por auctoridad de los antiguos... dizen que...). En (2) las palabras ajenas se introducen a modo de discurso indirecto (dixo que aquella muerte se fazía), o directo (les dixo: - Esta muger...), procedimientos sintácticos bien conocidos que permiten poner en contacto un discurso con otro y que, como han expuesto Girón Alconchel (1988, 1989, 2000, en prensa) y Méndez (1999) entre otros ${ }^{19}$, distan de ser los dos únicos posibles modos de citar. Sí

17. Vid. Graciela REYEs, Polifonía textual. la citación en el relato literario, Madrid: Gredos, 1984; id., Los procedimientos de cita: estilo directo y estilo indirecto, Madrid: Arco-Libros: 1993; Jacqueline AUTHIER-RÉVUZ, «Hétérogénéité montrée et hétérogénéité constitutive : éléments pour une approche de l'autre dans les discours», DRLAV, 26, 1982, p. 91-151; Catherine KERBRATOrecchioni, La enunciación. De la subjetividad en el lenguaje, Buenos Aires: Hachette, 1986.

18. Álvaro de Luna, Virtuosas e claras mugeres. Edición, estudio preliminar y notas de L. PONS RODRÍGUEz. Burgos: Instituto Castellano y Leonés de la Lengua.

19. Vid. José Luis GIRÓn AlCONCHEL, «Sobre la lengua poética de Berceo (y II): el estilo indirecto libre en los Milagros y sus fuentes latinas», Epos, 4, 1988, p. 145-162; id., Las formas del discurso referido en el Cantar de Mio Cid, Madrid: anejo 44 del BRAE, 1989; $i d$., «Sintaxis y discurso en el español del Siglo de Oro (contribución a la historia del discurso indirecto libre)», 
son los más llamativos, los mejor tratados normativamente, y los más claramente delimitables en función de sus rasgos sintácticos, caracterizados por las gramáticas y retóricas como oratio recta (estilo directo) y oratio obliqua (estilo indirecto), pero no son los únicos:

Aunque las Gramáticas suelen estudiar el discurso directo y el discurso indirecto dentro de la oración compleja (yuxtaposición y subordinación de oraciones, respectivamente), la realidad muestra que una de las características del enunciado de discurso referido es que trasciende los límites de la sintaxis oracional y se instala en la sintaxis del discurso (la única que puede dar cuenta de la interrelación dinámica entre lo propio y lo ajeno) [...] Esto hace [...] que las formas de referir el discurso ajeno deban verse como integrantes de un continuum en el que no siempre hay formas «puras» (entendiendo como tales los canónicos discurso indirecto y discurso directo que describen las gramáticas) sino que se pasa insensiblemente de unas formas a otras ${ }^{20}$.

Lo que se sale de estos dos estilos es válido y posible, y no únicamente propio (como se quiso pensar en su momento) de la literatura moderna, por eso no es aceptable que se condenen formas de reproducción de discurso como el llamado «discurso indirecto mimético» ${ }^{21}$, caracterizado por presentar estilo directo pero con marcas que recuerdan al indirecto, ya que está introducido por un verbo de decir y una oración completiva ${ }^{22}$.

Tal fenómeno no se advierte en el tratado de don Álvaro de Luna, que, no obstante, sí muestra algunos casos interesantes de procedimientos citativos no agrupables bajo los clásicos marbetes de estilo directo e indirecto; tal es, por ejemplo, el caso de las siguientes muestras:

Vozy Letra, 11/1, 1989, p. 93-113; id., «Tradiciones discursivas y gramaticalización del discurso referido en el Rimado de Palacio y las Crónicas del Canciller Ayala», in: Actas del Coloquio internacional sobre tradiciones discursivas (Tubinga, diciembre 2005), en prensa; Elena MÉNDEZ GARCíA DE PAREDES, «Análisis de la reproducción del discurso ajeno en los textos periodísticos», Pragmalingüística, 7, 1999, p. 99-128; id., «Análisis de las formas de introducir el discurso ajeno en los textos periodísticos: el contexto reproductor», in: J. J. DE BusTOS TOVAR et al. (ed.), Lengua, discurso, texto..., p. 2081-2098.

20. E. MÉNDEZ, «Análisis...», p. 106-107.

21. La terminología es de Brian MAC HALLE, «Free Indirect Discourse : A Survey of Recent Account», PTL: A Journal for Descriptive Poetics and Theory of Literature, 3, 1978, p. 249-287, y ha sido posteriormente revisada por otros autores.

22. Edición de Lewis J. HutTON: Arboleda de los enfermos. Admiraçión operum dey, Madrid: BRAE, 1967, p. 37-109, p. 88. La condena normativa a este modo de referir (manifiesta, por ejemplo, en la mayoría de los libros de estilo de la prensa española) ha provocado que, cuando en alguna ocasión se ha detectado este tipo de reproducción en textos antiguos, se haya malinterpretado su función. Así, ante la frase: «Juan de Ayala respondio que a los reyes yo los sirvo» en un documento murciano bajomedieval, Diez de Revenga - Igualada se muestran reacias a admitir que estemos ante una manera más de referir discurso y lo interpretan como un lapsus calami que hizo aparecer un que superfluo (también consideran la posibilidad de que sea un rasgo típico de la lengua hablada, aunque ven esta hipótesis como menos probable). Vid. Pilar DíEZ DE REvenga TORRes; Dolores A. IGUALADA Belchí, «El texto jurídico medieval: discursos directo e indirecto», Cahiers de linguistique hispanique médiévale, 17, 1992, p. 127-152, p. 137. 
(2) Entonce le dixo el profeta e sacerdote Helí [a Ana, madre de Samuel] que se fuese en paz ca Dios conplirá las sus peticiones, ella respondió:

-Plega a Dios que ello sea así (fol. 32r ${ }^{\circ}$ ).

(3) [Historia de María Egipciaca, diálogo entre la santa y Zósimo - Gozinias - ]

E afincándola él, dixo:

- Yo fui nascida en Egipto, e a los doze años de mi edad fui a Alixandría, e dime diez e seis años a pública luxuria que non me negué a ninguno.

¡O umilldad grande!, aunque prevalescía entonces por mucha santidad, pero non ovo verguença de confesar la fealdad de su floresciente edad. ¡Grand cosa, o santo Dios, de dentro e de fuera bien e santamente bevir, e qué grandes cosas estas! Aviendo onbres de aquella partida acordado de navegar a Jerusalén por adorar la cruz, dixo que avía rogado a los marineros que la llevasen consigo, e ellos demandándole flete, dixo: «Yo non poseo cosa que vos dé por flete sinon mi cuerpo, aquel aved».

- E esto dicho rescibiéronme en la nao.

E desque llegó a Jerusalén e vino a la puerta de la iglesia en uno con los otros diz que la echaron, e que luego [...] (fol. 179v ${ }^{\circ}$.

En ambos casos se observa una evidente permeabilidad en lo citado de elementos de la cita original. En (2), las palabras del sacerdote Helí son narradas en pasado y se introducen en una frase en estilo indirecto en la que el segundo verbo (le dixo que se fuese en paz ca Dios conplirá las sus peticiones) corresponde al eje deíctico del discurso original frente al «futuro del pasado» condicional que cabría esperar (cumpliría). En (3) estamos ante un fenómeno más complejo: el locutor reproduce en discurso directo el relato de santa Maria Egipciaca, y lo reproduce con las señales demarcativas pertinentes, con verbo introductor dixo cuyo sujeto elíptico es ella. Tras ese discurso directo, vuelve a tomar la palabra el locutor, que glosa argumentativamente la enunciación anterior y hace progresar el relato introduciendo en discurso directo, y de nuevo con contexto de reproducción, las palabras de María Egipciaca a los marineros. Pero entonces - siempre que se coincida con la puntuación que se ha dado al fragmento - aparece un discurso directo de la santa que remite al verbo de decir que figura antes del paréntesis elogioso del autor - e afincándola él, dixo-, lo que justifica la ausencia de contexto de reproducción. Tal discurso directo asume como contenido temático la enunciación previa en discurso directo introducida por el locutor. De esta forma, al reutilizarse la misma marca introductora del discurso primero, el autor renuncia a ser él el que narre la resolución de la escena, que encomienda a las propias palabras de la santa. De esta forma, parece que la santa está viva y presente en el momento de compilación de su vida, «codo con codo» con el que el que la cuenta, hablando de ella misma (rescibiéronme) en el pasado del mundo narrado. Sólo podemos 
explicar este fenómeno asumiendo que la transmisión de discurso referido se hace a partir de patrones no discretos, que integran un continuum, sobre los que, en este caso, están actuando convenciones y reelaboraciones que han provocado una situación insólita desde el punto de vista enunciativo, en la que se confunde lo que la santa dijo a los marineros, que sería pasado aun en el discurso original y lo que la santa dice en presente en el discurso original a Zósimo.

Con todo, no son muy habituales y en Virtuosas e claras mugeres, salvo los dos ejemplos ya comentados, se siguen las configuraciones citativas clásicas de estilo indirecto y directo. Los pasajes en estilo directo aparecen en el curso de todo el texto, por ejemplo, en el Libro Primero o de mujeres bíblicas los hallamos en las historias de Susana y Ana; también en el Libro Segundo o de mujeres grecorromanas, por ejemplo en la narración de la vida de Lucrecia - en las palabras de Sesto Tarquino a Lucrecia o en lo que luego dice ésta a su marido Colatino-. Aun así, en los dos primeros libros de Virtuosas e claras mugeres es realmente escasa la inserción de pasajes en estilo directo. En cambio, este rasgo cambia notablemente en el Libro Tercero o de vidas de santas, en el que son muy frecuentes los pasajes que recrean estilo directo y, más concretamente, son comunes los diálogos. Nuestros cómputos arrojan estos datos: el Libro Tercero está constituido por 24473 palabras. De ellas, 4857 pertenecen a parlamentos en estilo directo, por lo que el discurso referido copa un 19,8\% del libro de las santas. Si incluimos en el cálculo los elementos del marco reproductor (verbo de decir, personaje locutor, etc.) la proporción subiría hasta aproximadamente el $25 \%$.

Como «sucesión de estilo directo» ${ }^{23}$ podemos considerar los enunciados de diálogo, que suponen la aparición directa sin apenas mediatización de las palabras ajenas. El diálogo ${ }^{24}$ se define como una «interacción verbal basada en el intercambio de turnos de palabras, de forma que los interlocutores se intercambian sucesivamente los papeles de emisor y de destinatario», categoría básica del lenguaje hablado.

En el Libro Tercero del tratado de don Álvaro hay escenas dialógicas en las narraciones de las vidas de las santas Ágata, Anastasia, Caterina, Cecilia, Crispina, Eufemia, Eugenia, Inés, Isabel, Juliana, Lucía, M Egipciaca, Magdalena y Petronila. Hay estilo directo, pero no propiamente diálogo (falta el componente «sucesión») en las vidas de Paula, Teodora, Justina y Margarita, en tanto que falta por completo la mímesis en estilo directo

23. J. L. GiRón ALCONCHEL, Las formas del discurso..., p. 87.

24. El término diálogo puede evocar significados muy diversos: vid. Elena ROJAS MAYER, El diálogo en el español de América. Estudio pragmalingüístico-histórico, Madrid: Iberoamericana, 1998, p. 121-128 sobre los referentes de ese concepto en la prensa actual. 
en las biografias de las santas Ana, Cassia, Elisabet, Julia, Marta, Marina y Pelaya.

La razón que explica esa descompensación en el peso de los parlamentos dialogados entre los libros primero y segundo y el tercero de Virtuosas e claras mugeres está en las distintas fuentes que hay tras cada uno de ellos. Si para biografiar a mujeres virtuosas bíblicas y grecorromanas, don Álvaro acude al Antiguo Testamento y a autores como Tito Livio, Valerio Máximo, San Jerónimo o Boccaccio, en el Libro Tercero, en cambio, la fuente está en el repertorio latino de vidas de santos puesto en circulación por Jacobo de la Vorágine en la Legenda aurea (c.1264). Tanto en ese repertorio como en otras manifestaciones hagiográficas, la presencia de diálogos era un componente fundamental, un modo de dramatización de la secuencia narrativa que animaba al auditorio:

La aparición del diálogo en los textos líricos o narrativos se ha interpretado como una aproximación al género dramático y a la vez como un signo de dinamismo o de estilo realista ${ }^{25}$.

Esta dramatización se repetía como una de las marcas de la tradición discursiva de las vidas de santos, y estaba, además, codificada como recomendación por las retóricas, que exhortaban a la utilización de diálogos como un mecanismo para dotar de viveza a la narración, y para conseguir la autentificación del discurso. La figura de la sermocinatio, regulada en todas las retóricas, consistía en «fingir, para caracterizar personas naturales (históricas o inventadas) dichos, conversaciones, monólogos o reflexiones inexpresadas de las personas correspondientes» ${ }^{26}$.

Cierto es que, en esa operación de retextualización que parte desde la fuente hagiográfica a su propio tratado, don Álvaro cambia notablemente el aspecto lingüístico original del relato hagiográfico, en planos diversos (Pons en prensa), entre ellos el relativo al volumen de pasajes en estilo directo. Donde hay diálogo en Virtuosas e claras mugeres, tenemos escenas más cortas de las que hay en el texto de partida porque don Álvaro ha convertido algunos de los parlamentos originales en discurso indirecto. Igualmente, las vidas de santas sin diálogos suelen contenerlos en la fuente. Pese a ese recorte en la proporción de fragmentos de diálogo, conserva

25. C. Bobes Naves, op. cit, p. 153.

26. Heinrich Lausberg, Manual de retórica literaria. Fundamentos de una ciencia de la literatura, Madrid: Gredos, 3 vol., edición española de 1967, traducción de J. PÉREz RIEsco de Elemente der Literarischen Rhetorik, 1960, p. 239, § 235. Sobre la inserción de discurso directo como modo de amplificatio, véase el reciente trabajo de Belén ALMEIDA, «La creación de discurso directo e indirecto en la historiografía alfonsí», in: Actas del V Congreso internacional de historia de la lengua española, Madrid: Arco-Libros, vol. III, p. 2639-2651. 
el Libro Tercero un cantidad interesante de escenas dialógicas en las que merece la pena detenerse ${ }^{27}$.

En función de los personajes que intervienen, podemos separar dos tipos de escenas dialógicas en ese Libro Tercero de Virtuosas e claras mugeres:

a) pasajes dialógicos en que la santa entabla conversación con algún personaje secundario (su madre, esposo, rescatador, el demonio [...]):

(4) La cuitada madre suya, oyendo esto, rasgó sus vestiduras e aguijó a la cárcel e echose a los pies de la fija e con lágrimas segund creo dixo:

- Fija mía, Crispina, lunbre de mis ojos, ave piadad de mí. Ella, encendido el coraçón en el amor de Dios le dixo:

- ¿Qué dizes de tu fija? Sabe que el nonbre de Dios está fincado en mi coraçón (fol. $194 \mathrm{v}^{\circ}-195 \mathrm{r}^{\circ}$ ).

b) interrogatorios en que un juez o un adelantado plantea preguntas o dirige amenazas y reprimendas a la santa, antes o después de martirizarla:

(5) Entonces el adelantado movido con ira dixo:

— ¿Por qué fablas así tan soberviamente?

Sicilia respondió:

- Non fablo sobervio como piensas, mas firme (fol. $205 \mathrm{v}^{\circ}$ ).

Estos diálogos -interrogatorio son notablemente más extensos que el tipo anterior. En ellos se refleja un enfrentamiento verbal entre la santa y su martirizador, un pagano que quiere hacerla, sin éxito, descreer del cristianismo. Entre ambos personajes se establece un juego verbal a base de intervenciones fuertemente argumentativas. Los diálogos - interrogatorio están mayoritariamente constituidos por macroactos de habla en los que el martirizador produce enunciados con valor ilocutivo instantivo: preguntas (valor inquisitivo de petición de información), amenazas (valor ejercitativo, perlocutivo) y mandatos. Es habitual que esos actos de habla se presenten en sucesión: el juez, o el adelantado, o gobernador, una autoridad cualquiera, hace llamar a la santa y le pregunta sobre su condición cristiana. Luego, esas preguntas, probada la tozudez de las santas en declarar su fe cristiana, van evolucionando hacia actos de amenaza, de ofrecimiento, de repulsa, de extrañeza hacia su actitud, y devienen en mandatos por los que el martirizador hace retirar a la santa de su vista y dispone su martirio.

Pese al nombre de diálogos - interrogatorios, el diálogo no consiste, sistemáticamente, en la formulación de preguntas a la santa; muchas de las

27. La consideración de cómo se distribuyen y organizan internamente los diálogos de Virtuosas e claras mugeres supone un análisis de estas escenas en la reelaboración que se hizo de ellas en un texto del siglo XV, pero también - dada la utilización clara de la fuente hagiográfica de Vorágine en su traducción romance - una aproximación a los mecanismos lingüísticos de los diálogos hagiográficos, sin estudiar aún. 
intervenciones del martirizador son amenazas («cesarán las palabras quando viniéremos a las feridas», $175 \mathrm{v}^{\circ}$ ), ofrecimientos, contraargumentaciones... Se establece un combate entre la verdad (las santas) y el error (los adelantados), pero no con carácter alegórico - como era también común en la Edad Media- sino a través de individuos concretos que participan de una realidad histórica. Son diálogos polémicos, pues no hay solución final para el problema debatido: el final lo dan los hechos: la persistencia en su fe de la mujer y su consecuente muerte. Sin embargo, los «adelantados» de Virtuosas e claras mugeres son sentidos como perdedores del combate dialéctico por un receptor - lector cristiano, antipagano -con la curiosa paradoja de que esos dioses que aborrecen las santas son exempla en el Libro Segundo-. Se distinguen también nuestras escenas en esto del diálogo catequético, donde hay una transmisión de doctrina desde el maestro al discípulo.

En ambos casos, estamos — pero especialmente en la variedad del diálogo interrogatorio - ante interacciones dialógicas escoradas fuertemente hacia el polo de la distancia comunicativa. Así se comprueba si aplicamos a los diálogos que forman nuestra base de análisis los diez parámetros relativos a condiciones comunicativas que proponen Koch y Oesterreicher ${ }^{28}$ como elementos que desplazan el acto comunicativo hacia los ámbitos de la distancia o la inmediatez comunicativa. Tales parámetros son todos (salvo la copresencia espacio - temporal) escalares:
Inmediatez comunicativa
Distancia comunicativa
Comunicación privada.
Comunicación pública.
Interlocutor conocido.
Interlocutor desconocido.
Fuerte componente emocional.
Escaso componente emocional o expresivo.

Anclaje en la situación o en la acción. Separación de la situación o la acción.

Anclaje en el eje referencial.

Distancia de los objetos y personas referidas.

28. P. KOCH, W. OESTERREICHER, op. cit., 2.3.1; vid. también, id. «Langage parlé et langage écrit», in: Günter HolTUS et al. (ed.), Lexikon der romanistischen linguistik, I, 2, Tubinga: Niemeyer, 2001, p. 548-628; Andreas WESCH, «Acerca del análisis de la lengua hablada», in: A. MARTíNEZ (ed.), Estudios de filología hispánica Estudios lingüísticos y literarios, Granada: Universidad de Granada, 2001, p. 111-128; Araceli LóPez SERENA, Reseña a P. KocH y W. OEsTERREICHER, Gesprochene Sprache in der Romania: Französisch, Italienisch, Spanisch, in: Lexis XXVI, 2002, p. 255271. Para una aplicación de los términos inmediatez / distancia comunicativa en la historia del español, vid. Lola PONS RODRÍGUEZ, «Una reflexión sobre el cambio lingüístico en el siglo XV», in: Actas del V Congreso andaluz de lingüistica general. Homenaje al profesor F.A. de Molina Redondo, Granada: Granada Linguistica Collectae, vol. 3, p. 1563-1577. 
Copresencia espaciotemporal.

Intensa cooperación comunicativa.

Alto grado de dialogicidad.

Alto grado de espontaneidad.

Libertad temática.
Separación espaciotemporal.

Mínima cooperacion comunicativa.

Bajo grado de dialogicidad.

Bajo grado de espontaneidad:

Alta fijación temática

Una caracterización del comportamiento comunicativo de los interlocutores de estos diálogos en relación con los condicionantes del contexto y la situación fijados de acuerdo con este haz de valores los sitúa, efectivamente, más inclinados al dominio de la distancia comunicativa.

Estamos, en general, ante diálogos que reproducen una comunicación pública. El grado de privacidad de la comunicación es, obviamente, distinto según el tipo de diálogo ante el cual nos situemos. Hay casos de conversación privada, como la que Zósimo y María Egipciaca mantienen en el desierto. En cambio, aunque del escenario de los interrogatorios no se nos suele informar ${ }^{29}$, se entiende, por defecto, que transcurren en un lugar donde hay un cierto grado de publicidad, pues en él no sólo se encuentran la santa y su martirizador, sino también sayones, soldados o sabios: terminado el interrogatorio, o interrumpido abruptamente por el pagano, es común que éste se dirija a esos personajes para solicitarles algo. Ahora bien, esto no convierte al diálogo jamás en un intercambio poliádico: aunque haya otros personajes presentes en la comunicación, ninguno de ellos irrumpe en escena - estamos ante un acto verbal muy formalizado - y el diálogo se reduce en el plano de los interlocutores a la santa y el martirizador.

El grado de familiaridad de los interlocutores es también diverso. Algunos diálogos del Libro Tercero se producen entre interlocutores conocidos, por ejemplo, entre Lucía y su madre (fol. $\left.174 \mathrm{v}^{\circ}\right)$. Pero en los casos de diálogo -interrogatorio, la interacción es socialmente no convergente. Los interlocutores no se conocen y además hay una relación asimétrica entre ellos, una relación de [+ poder], [solidaridad]. Pese a ello, hay un alto grado de componente emocional y expresivo, característica que está más orientada hacia la esfera de la inmediatez. El objeto de la discusión ocasiona un alto grado de expresividad entre los interlocutores; el conflicto que causan los distintos intereses de los participantes en estos intercambios dialógicos los

29. Sólo en la historia de santa Caterina hemos encontrado referencias directas al escenario de interlocución y ahí sí hay explicitamente un aviso sobre el aparte que se hace: «Fablo con él [el César] ante la puerta del tenplo por muchas e diversas conclusiones de silogismos, e despues apartolo a fabla familiar e dixole [...]» (fol. 207r ${ }^{\circ}$. 
hacen crispados. Aparecen insultos, descalificaciones ${ }^{30}$ : santa Ágata le dice a Quinciniano « $\mathrm{i}$ cruel e vano tirano!» (fol. 171v), y tras una amenaza, le contesta «Cuitado, tus palabras son locas e malas» (fol. 172vo); santa Lucía le dice a su martirizador Pascual: «A vosotros llamo yo corronpedores de la voluntad, que trabajáis por aconsejar al ánima [...]» (fol. 175v $\mathrm{v}^{\circ}$.

Los interrogatorios tratan de ser espejos lingüísticos de la ideología de los personajes: las santas se presentan sufridas pero también inteligentes, despiertas, ágiles en sus respuestas; los martirizadores, poderosos, pero también estólidos y atribulados en sus actuaciones. Hay, por un lado, un desnivel de poder - el mártir está protegido por el poder divino pero el martirizador tiene el poder real - y, por otro lado, un desnivel cognoscitivo: el mártir no quiere saber del martirizador ni sus palabras cambiarán su modo de pensar, el martirizador quiere saber de la mártir. La emocionalidad está también presente en el tono amenazante de las respuestas, la ironía... Pese a ello, no es muy común el uso de interjecciones y son escasos los vocativos ${ }^{31}$.

Por recoger actos de habla amenazantes, los diálogos entre las santas y otros personajes también reúnen interesantes muestras de denuestos: santa Margarita interpela así al diablo tras haberlo derrocado: «Sobervio diablo, agora serás derrocado so los pies de la muger» (fol. 189r ${ }^{\circ}$ ); santa Crispina llama a su padre - que ha mandado que la torturen - «tirano y loco desaventurado» (fol. $195 \mathrm{r}^{\circ}$ y fol. $196 \mathrm{r}^{\circ}$ ). En otras escenas dialógicas de menor hostilidad, las llamadas entre interlocutores son menos conflictivas: «Muy dulce Juliana mia, ¿por qué burlas así de mí?» (fol. $177 \mathrm{r}^{\circ}$ ) es la frase que le dice a Juliana su marido, el adelantado con el que se acaba de casar y al que rechaza unirse carnalmente.

En cuanto al anclaje de los actos comunicativos, se encuentran ya distanciados de la situación - cuando se discute sobre la condición divina

30. Que poco emparentan con las que se documentan en documentos medievales donde se recogen muestras de actos lingüísticos insultantes, vid. Mónica CASTILLO LLUCH, «De verbo vedado: consideraciones lingüísticas sobre la agresión verbal y su expresión en castellano medieval», Cahiers de linguistique et de civilisation hispaniques médiévales, 27, 2004, p. 23-35.

31. Lo que contrasta, por ejemplo, con la construcción de los diálogos en Berceo, en cuya obra, hay, según Cano «una abrumadora mayoría» de vocativos, especialmente al inicio de los pasajes en estilo directo (vid. Rafael CANO AGUILAR « La sintaxis del diálogo en Berceo», in: Homenaje a la Dra. Ofelia Kovacci. Buenos Aires: EUDEBA, p. 113-156. En cuanto a las interjecciones, encontramos en dos ocasiones ay, concretamente en la forma ay de mí, pronunciada en son de lamento por dos personajes, fuera en ambos casos de diálogos -interrogatorios: la santa Teodora a su marido «Marido bueno ¡ay de mí!, ¿con quántos trabajos enflaquezco yo mi cuerpo...?» (fol. 186r ${ }^{\circ}$ ); «El diablo fuyendo dio bozes: ¡Ay de mí, mesquino!» (fol. 178vo ${ }^{\circ}$. Más frecuente es «O», que, además de ser un recurso constantemente empleado por el autor para ensalzar a la protagonista con una función encarecedora, admirativa, aparece también en discurso de personajes: « $\mathrm{O}$ mancebo muy dulce e muy amado!», dice santa Cecilia (fol. 203v ${ }^{\circ}$ ) a su recién esposado Valerio; «— $\mathrm{O}$ malvado!» llama el adelantado a santa Eugenia, a quien cree varón (fol. $198 \mathrm{v}^{\circ}$ ). 
de Cristo y errada de los dioses - ya ligados a ella, cuando las palabras se centran en el siguiente castigo que será infligido a la mártir o en la reacción de ésta ante el martirio. El apoyo contextual es nulo y, además, son diálogos apenas contextualizados. No sólo faltan datos sobre situación y entorno, además, el propio diálogo se ofrece reducido a los intercambios de mayor peso para la trama. No se presentan nunca las secuencias de cierre ni de apertura ${ }^{32}$.

Hay, obviamente, copresencia espacio - temporal entre los interlocutores, pues estamos hablando de diálogo in praesentia, cara a cara; con todo, no hay un marco discursivo familiar en los casos de interrogatorios y sólo en algunos casos en el otro tipo de diálogos. La inexistencia de este marco discursivo familiar y el tipo de acto de habla - interrogatorio hostilante el que nos encontramos explica que el grado de cooperación no sea alto ni equilibrado entre los interlocutores. Si en este sentido es constantemente el martirizador el que tiene mayor libertad para intervenir en la producción discursiva, en el sentido más griceano de cooperación la cuestión es justamente opuesta. El martirizador realiza afirmaciones o preguntas y dirige estímulos comunicativos que dan con la poca colaboración de las mártires. Por eso se pasa primero por una fase suasiva y después se llega a la amenaza, al aviso de que «cesarán las palabras» ${ }^{33}$.

Resultan indisociables para nuestro análisis los parámetros restantes de cooperación, dialogicidad y grado de espontaneidad de la comunicación. Observamos que en estos diálogos la toma de turno está predeterminada y su funcionamiento es automático, casi mecánico. La comunicación está algo preparada de antemano, pero las réplicas, espontáneas, orientan su desarrollo. No se da, pues, ese rasgo de ausencia de planificación propio de los registros coloquiales, tampoco aparecen referencias accesorias e inesperadas que se desvíen del núcleo común del diálogo, segmenten el acto comunicativo o atenúen el nivel de cohesión de los enunciados. Los interrogatorios no son progresivos, en su desarrollo la santa no quiere crear ni aclarar sentidos, no se progresa hacia un acuerdo, se reincide constantemente en los puntos ideológicos que dan lugar al enfrentamiento. La escena se termina convirtiendo, en algunos casos, en un diálogo erístico, una mera disputa. En ella, no hay libertad temática: se habla siempre de la posible condición cristiana de las víctimas.

Dejando a un lado los diálogos entre las santas y personajes benévolos (como familiares o rescatadores), estamos ante diálogos que reproducen interacciones hostiles, una clase de intercambio comunicativo que

32. En los diálogos renacentistas sí las hay, aunque a veces sea una «excusa formal sobreimpuesta», según S. IGLESIAS RECUERO, «Elementos conversacionales...», p. 392.

33. A veces la fase suasiva es abreviada por don Álvaro, que sólo refleja en forma directa las escenas más violentas, que lo son tanto de un lado como de otro. 
se encuentra muy poco representado en la literatura y, en general, en la prosa medieval castellana. Cierto es que se cuenta con el antecedente de los debates poéticos ${ }^{34}$, pero no consideramos que se deba aplicar la denominación de interacción hostil con justeza a esa clase de debates poéticos: en ellos hay un proceso de alternancia verbal entre dos oponentes, pero se trata de una interacción verbal hostil convencionalizada en género literario. En el caso de los debates poéticos de los cancioneros, estamos más bien ante juegos lingüísticos que no creemos tengan parangón con el tipo de interacción discrepante que pintan nuestras vidas de santas ${ }^{35}$.

2. En la caracterización de la construcción discursiva de estos pasajes de discurso referido, atenderemos ${ }^{36}$, en primer lugar, al contexto (o marco) reproductor que se utiliza para introducir la cita. Seguimos a José Luis Girón Alconchel en su definición de estos elementos: «el enunciado de discurso referido es, desde un punto de vista formal, la integración de un discurso reproducido en un marco reproducton ${ }^{37}$. Los elementos que pueden diferenciarse en este marco reproductor son dos: las señales demarcativas, precisas en todo discurso referido, constituidas por el sujeto - personaje, el verbo de comunicación y la relación sintáctica que establecen la cita y su contexto, y los indicios externos de reproducción, que aparecen facultativamente para ordenar y orientar lo dicho.

Los contextos reproductores que encontramos en Virtuosas e claras mugeres son bien escuetos. Suelen estar limitados a las señales demarcativas de sujeto - personaje y verbo de comunicación, éste contiguo al discurso reproducido o, en algún caso aislado, separado por aditamento que introduce indicio modalizador. En cuanto a los indicios externos de reproducción, sólo se encuentra alguna muestra ocasionalmente:

34. Manuel ARIZA ViguerA, «La lengua de los debates medievales (género y lengua literarios)», in: Serta Philologica F. Lázaro Carreter, I., Madrid: Castalia, 1983, p. 59-66.

35. Son casos comparables, en cuanto a la tipología del «diálogo» los que estudia Marcel BAX, «Ritual Levelling. The Balance between the Eristic and the Contractual Motive in Hostile Verbal encounters in Medieval romance and Early Modern Drama», in: Historical Dialogue Analysis, Amsterdam-Philadelphia: John Benjamins, 1999, p. 35-80, entre ellos, el diálogo que los caballeros medievales en la épica carolingia entablaban antes lanzarse a jugar armas. En los cancioneros se pone a prueba la capacidad verbal y el ingenio para construir un mensaje en que se retome la selección léxica y se dé la vuelta a los insultos del contrario. En el debate cancioneril, y en el juego de armas, hay un aspecto que creemos fundamental: lo colaborativo, parte del género en ambos casos. Cada uno de los participantes colabora (si bien competitivamente) en el juego. Los diálogos de vidas de santas, en cambio, pretenden no reflejar ese carácter colaborativo.

36. Como material de estudio no nos reduciremos a los diálogos, emplearemos todas las intervenciones en estilo directo que hay en el libro dedicado a las santas, no sólo aquellas que producen intervenciones reactivas en estilo directo.

37. J. L. GIRÓN ALCONCHEL, Las formas del discurso..., p. 72. 
(6) Ella le dixo con grand coraçon e esforçado: -Nin sacrificaré a los aborrescibles dioses, nin me enmanzillaré... (fol. 162 $\mathrm{v}^{\mathrm{o}}$ );

(7) ¡O muy santa umildad! Dizen que los ojos puestos en tierra respondió (fol. $198 \mathrm{v}^{\circ}$ );

(8) Al qual él respondió a bozes: (fol. 204ro $)$;

(9) Dixo con grande firmeza al mensagero que traxo las nuevas: - Non me dizes cosa nueva nin que yo non aya esperado (fol. $47 v^{\circ}$ ).

En algún caso, la aparición de indicios modalizadores parece estar destinada a resituar al lector en el diálogo después de un inciso. Así ocurre en el interrogatorio del adelantado Almaquio a santa Cecilia (fol. 205r-v ${ }^{\circ}$ ), un largo cuestionario donde el contexto de reproducción se limita en todas las intervenciones a locutor y verbo de comunicación. Cuando ese interrogatorio es interrumpido por el autor, Álvaro de Luna, con un inciso argumentativo, y reanudado luego con un nuevo parlamento del adelantado Almaquio, se acompañan indicios externos modalizadores:

(10) ¡O cosa muy magnífica digna de notable e grand muger que muestra que la honrosa muerte es de anteponer a la vida fea!, la qual muchos buenos e de muy resplandescientes juizios muchas vezes escogieron por non pecar contra la ley natural.

Entonces el adelantado movido con ira dixo:

- ¿Por qué fablas así tan soberviamente?

Sicilia respondió... (fol. $\left.205 \mathrm{v}^{\circ}\right)$.

Las señales demarcativas suelen presentar, pues, una configuración básica con los componentes constantes de <personaje que habla + verbo de comunicación que introduce el parlamento en estilo directo $>$ :

(11) Al fin después de muchas cosas dichas de cada cabo, el viejo dixo:

-Yo soy apostol de Dios... (fol. 172r ${ }^{\circ}$ );

(12) El juez le dixo:

- Entendía que eras tornada en tu primero buen seso, e alegrávame porque te avías acordado de tu dignidad maguer tarde (fol. $\left.200 \mathrm{r}^{\circ}\right)$.

Pero hay algunos pasajes en que esa configuración estándar se altera. En dos fragmentos de las vidas de $\mathbf{M}^{\mathrm{a}}$ Egipciaca y Juliana, las señales demarcativas se reducen a la explicitación del sujeto locutor, sin verbo de comunicación, presentado el discurso referido como si fuese teatro que se lee escrito. En el manuscrito base de la edición de la obra (BU Salamanca 207) aparecen las frases yuxtapuestas, sin marcas gráficas o sólo con punto bajo antes y después del sujeto locutor; la regulación editorial de la puntuación separa claramente locutor y enunciado: 
(13) Al qual dizen que el adelantado dixo:

- Muy dulce Juliana mía, ¿por qué burlas así de mí?

Juliana dixo:

- Si al mi Dios bien e derechamente adorares faré a tu guisa; en otra manera yo no sosegaré contigo.

El adelantado:

- Esto yo non lo puedo fazer, ca si lo fiziese el enperador me castigaría por pena de muerte.

Juliana:

- Si tanto miedo has del enperador que sabes que es mortal, ¿cómo quieres que yo non aya miedo de Dios inmortal? Por tanto, faz lo que podrás que a mí non podrás engañar (fol. $\left.177 \mathrm{r}^{\circ}\right)$.

(14) Él, en oyendo su nonbre, maravillose e diole el manto e echado en tierra rogola que lo bendixiese. Ella dixo:

- A ti, padre muy bueno, es sabido que pertenesce el oficio del bendezir, que eres honrado por dignidad sacerdotal.

E después que él vio que el su nonbre e oficio era a ella conoscido, movido por mayor maravilla, rogola afincado que lo bendixiese:

María:

-Bendígate Dios redemptor de nuestras ánimas.

E en quanto ella orava con las palmas tendidas, vídola cerca de un codo levantada del suelo, e estonces aquel grande abad començó a dubdar que por ventura non fuese espíritu que infinitosamente dava obra a oraciones:

María:

- Perdónete el muy alto príncipe de todas las cosas si entendiste que yo era espíritu suzio acostunbrada a pecados.

Entonces Gozinias la començó a conjurar por el Señor que le manifestase quién era.

María:

- Padre, perdona, que si mis costunbres e vida te contare, espantado como de serpiente echarás a fuir, tus orejas se enojarán con mis palabras e el aire se dañará con mis suziedades de pecados.

E afincándola él, dixo:

- Yo fui nascida en Egipto, e a los doze años de mi edad fui a Alixandría, e dime diez e seis años a pública luxuria que non me negué a ninguno (fol. $179 \mathrm{r}^{\circ}-\mathrm{v}^{\circ}$ ).

El fragmento transcrito en (14) es interesante también porque en él aparece sistemáticamente en discurso directo la enunciación de María y en discurso indirecto los intercambios de Gozinias - Zósimo - rogola que, començó a dubdar, la començó a conjurar, afincándola el... - Se consigue así el efecto de ceder el protagonismo de la escena a María, limitando y abreviando las intervenciones de Zósimo.

En alguna ocasión, las señales demarcativas desaparecen y no encontramos marco reproductor. Así ocurre en este diálogo entre santa Lucía y el cónsul Pascual, donde, después de varias intervenciones avisadas por la 
presencia de señales demarcativas, aparece una intervención de la santa sin anuncio alguno:

(15) E ella estando delante d'él e seyendo conbidada a los sacrificios de los ídolos respondió:

- El sacrificio agradable a Dios es visitar a los pobres e acorrerles en el tienpo de su nescesidad, e porque non tengo ál que ofrescer pueda, a mí mesma le do tanbién para ofrescer.

Pascual le dixo:

-Estas cosas puedes tú contar a qualquier loco cristiano tu igual, mas tales cosas non cunple fablarlas a mí que guardo las ordenanças de los príncipes.

- Mas yo curaré de guardar la ley de Dios: tú has temor de los príncipes del mundo, yo temo a Dios inmortal; tú te guardas de los enojar, yo trabajo de me desviar de ofender a Dios; tú piensas cómo fazerles cosa agradable, yo cobdicio sobre todas cosas a plazer a Jesucristo. Pues faz tú lo que entiendas que es tu pro, ca yo faré lo que entendiere que es provecho mío (fol. $175 \mathrm{r}^{\circ}$ ).

Hoy la presentación de diálogos con configuraciones como ésta es la habitual en los textos escritos, en ellos se da una fusión consciente de la voz del autor que narra y la voz interlocutiva de los personajes. Pero en tales diálogos se añaden marcas tipográficas inequívocas - espaciado de párrafo, guion inicial - que señalan el cambio de interlocutor. En el manuscrito original, ese parlamento de Lucía no está acompañado de ninguna de esas marcas, sólo del punto bajo que se emplea para separar frases simples y algunas compuestas, por lo que sin intervención editorial alguna resultaría un fragmento de ardua comprensión.

Hay que recordar, como información curiosa sobre la difusión y consideración que tenía la adjunción de avisos sobre tomas de palabras en diálogos, el testimonio de Alfonso de Cartagena en su carta de respuesta a Pier Cándido Decembrio sobre el encargo que el humanista italiano le había hecho de leer y repasar la traducción al latín que había realizado Decembrio del primer diálogo de La República de Platón. Tras comentarle Cartagena algunos puntos relativos a la traducción de algunos pasajes, le aconseja que en los diálogos introduzca siempre aviso de quien habla (parece que Decembrio finalmente siguió ese consejo):

Sic ergo ministerium per te mihi iniunctum expleui, sed hoc sic expleto paucula quaedam tibi amicabili mente dicere non incongruum putaui, quorum unum hoc est: Cum Plato per dialogi modum procedat, utillimum reor ut breuibus litteris quis loquitur annotetur, quod nedum Vbertus genitor tuus bene obseruauit, sed et alii famosissimi scriptores hoc in dialogis semper obseruant; sic Gregorius, sic Anselmus et alii paene innumeri, qui aliquos libros dialogizando scripserunt, hoc diligenter attendere curaerunt. Alioquin superuacua difficultas ex quadam ambiguitate oriretur, cum necessarium foret quod ex ipsa qualitate materiae, quae fuerint uerba Socratis, quae Glauconis, quae Trasimachi, semoto 
omni signo inquiramus, quae inquisitio profecto laboriosa legentibus plurimum erit. Consulerem ergo ut antequam libellus hic oculis subiciatur extraneis, in capite cuiuslibet orationis qui loquatur annotes.

Así pues, he cumplido la tarea que me encomendaste, pero, una vez así cumplida, he considerado conveniente decirte con propósito amigable algunos pormenores, de los cuales uno es éste: Cuando Platón se expresa por medio del diálogo, considero muy útil que se indique con abreviaturas quién habla, cosa que Uberto, tu padre, no sólo distinguió bien, sino que también otros escritores muy notorios lo observan siempre en los diálogos: así, Gregorio, Anselmo, y otros, casi innumerables, que escribieron algunos libros en diálogos, se preocuparon de advertirlo diligentemente. De no ser así, podría originarse una complicación gratuita a raíz de alguna ambigüedad, puesto que sería necesario que por la naturaleza misma de la materia y sin que medie ninguna señal averiguáramos qué palabras corresponden a Sócrates, cuáles a Glauco o cuáles a Trasímaco, averiguación sin duda extremadamente laboriosa para los lectores. Por tanto aconsejaría que antes de que el libro llegue a ojos extraños, anotes al comienzo de cada discurso quién habla ${ }^{38}$.

Otro asunto de interés es el repertorio de verba dicendi — verbos de decir o cualquier otro que discursivamente funcione como tal introduciendo y continuando el discurso - empleados en la inserción de estos pasajes de discurso referido. Fijándonos exclusivamente en los pasajes de estilo directo, observamos que la presencia obligada (o casi obligada, si consideramos los anteriores ejemplos 14, 15 y 16) de verbo de comunicación no es aprovechada por el autor para imprimir notas modalizadoras al contenido de lo referido. Se selecciona siempre un único verbo de comunicación, no aparecen los casos de dicendi coordinados como introductores de discurso directo que fueron comunes en la épica medieval (fabló $e$ dixo) y que se dan también hoy (saltó y dïo, cogió y dïo... $)^{39}$. Además, el elenco de verbos de comunicación es muy limitado. En el Libro Tercero, encontramos este panorama:

38. Texto latino y traducción de Tomás GonzÁlez Rolán, A. Moreno Hernández, Pilar SAQUERO SUÁREZ-SOMONTE" «Controversia alphonsiana (correspondencia de Alfonso de Cartagena con Leonardo Bruni y Pier Candido Decembrio [1436-1439])», in: Humanismo y teoría de la traducción en España e Italia en la primera mitad del siglo XV, Madrid: Ediciones Clásicas, 2000.

39. Anne Herlyn, «So he says to her, he says, "Well” he says...: Multiple Dialogue Introducers from a Historical Perspective», in: Historical Dialogue Analysis, Amsterdam-Philadelphia: John Benjamins, 1999, p. 313-330. 


\begin{tabular}{l|r}
\multicolumn{1}{c|}{ Verbo } & Ocurrencias \\
\hline decir & 151 \\
responder & 29 \\
oir & 2 \\
dar voces & 3 \\
amonestar & 1 \\
rogar & 1
\end{tabular}

Observamos que decir es el más frecuente — ocupa un 80,3\% de las ocurrencias, seguido muy de lejos por el $15,4 \%$ con responder-, dato que consuena con su situación de dominio en la introducción del discurso referido a lo largo de la historia del español ${ }^{40}$. La distribución relativa de decir y responder no es complementaria. Decir puede aparecer introduciendo discurso directo de todo tipo, en tanto que responder está ligado exclusivamente a intervenciones posteriores a una interrogación. El verbo responder aparece para dar pie a respuestas a preguntas, tipo de acto de habla que aquí practican más las santas (las interrogadas) pero que no está ligado exclusivamente a ellas, como se puede ver en este otro ejemplo, donde la santa es la que pregunta:

(16) Juliana le dixo:

—¿Quién es tu padre?

Respondió el diablo:

- Belzebuc, que a todos los males nos enbía (fol. 177v $\mathrm{v}^{\circ}$.

Puede también abrir un turno reactivo ante un ruego, como en:

(17) E como los guardas espantados por la grand lunbre se arredrasen e dexasen la cárcel abierta, algunos dizen que la rogaron que se fuese, a los quales ella respondió:

- Non quiera Dios que yo me vaya e pierda la corona de la paciencia señalada e con ella dé angustias a mis carceleros (fol. $172 \mathrm{r}^{\circ}-\mathrm{v}^{\circ}$ ).

El capítulo de santa Ágata es muy interesante, pues en el interrogatorio que se establece entre el gobernador Quinciniano y Ágata cada personaje

40. Dámaso Alonso ( «El anuncio del estilo directo en el Poema del Cidy en la épica francesa», in: Mélanges offerts à Rita Lejeune, vol. 1., Gembloux, 1969, p. 379-393) constata la repetición de decir como verbo introductor en el Quijote; P. DÍEZ DE REVENGA y D. IGUALADA, loc. cit., lo encuentran en un 76,33\% de las ocurrencias de verba dicendi (introductores de DD o DI) en un documento murciano bajomedieval. Sobre la distribución medieval y clásica de decir y fablar en la introducción de estilo directo, vid. Elisa BENAVENT ( «Límites entre la oralidad y la escritura: formas de "decir" el discurso directo en los relatos de ayer y hoy», Res Diachronicae, 1, p. 70-81) que defiende que fablar está en la historia del español más ligado al pretérito y aparece mucho en fórmulas retóricas fijadas por la tradición; decir, en cambio, goza de más libertad. 
tiene asignado constantemente un mismo verbo de comunicación: decir para Quinciniano y responder para Ágata, en distribución complementaria:

(18) Luego Quinciniano la mandó traer delante sí, e ella traída desque vino le dixo:

- ¿Qué condición es la tuya?

Ágata respondió:

- Soy clara e de noble linage, segund dizen todos mis mayores.

Quinciniano dixo:

-Si tú eres noble, ¿por qué tus costunbres muestran que eres sierva?

Ágata respondió:

- Porque soy esclava de mi Señor Jesucristo, por eso me do por sierva.

Dixo Quinciniano:

- Si de noble linage dizes que eres nascida, ¿por qué afirmas que eres esclava?

Respondió Ágata:

- Muy alta nobleza es la que bive so el suave yugo de Jesucristo.

Dixo Quinciniano:

-Escoge destas dos la que mejor te parescerá: o llega tus manos a las santas manos de los dioses, o gemirás so diversas maneras de tormento.

Respondio Ágata:

- Tal querría yo que fuese tu muger como tu deesa e tu Jupiter.

Entonces Quinciniano encendido en saña mandola ferir de bofetadas, e díxole:

- Non sobervies a Júpiter con tu atrevida boca.

Respondiole Agata:

- Maravillome de ti, varón prudente, venir a tan poco sentido que dizes que son tus dioses aquellos cuya vida tu nin tu muger non querrías seguir, e dizes que te es injuria si bivieres por la manera d'ellos. Si segund tú dizes son dioses, buena cosa te deseé, e si aborresces sus acostunbres eso mesmo sientes que yo.

Dixo Quinciniano:

- ¿Qué menester me faze a mí tan luenga fabla de palabras?: o da sacrificios a los dioses o por diversos e crueles tormentos te faré sallir el alma.

Respondiole Agata:

- Si me amenazas con las fieras animalias sin piadad, en echándolas el nonbre de Cristo desechada la braveza se amansarán; si con fuego... (fol. $170 \mathrm{v}^{\circ}-171 \mathrm{r}^{\circ}$ ).

La asignación de cada verbo no parece corresponder al tipo de acto de habla que realiza cada uno sino a la posición más o menos protagónica que se quiere asignar a las interlocuciones de cada personaje: el gobernador pregunta, insulta y amenaza, pero se le da el verbo decir, más neutro. Santa Ágata responde a los actos de habla del gobernador mostrando su valentía y fe en Dios. Se le concede más protagonismo asignándole un verbo que declara a cada momento su carácter contestatario. Pero ese reparto entre Quinciniano y la santa no se repite siempre: después hay un nuevo interrogatorio en que el personaje masculino utiliza tres veces decir y una responder, y la santa dos veces responder y una vez decir. 
Muy escasos son los otros verbos introductores: amonestar, rogar, dar voces, oir:

(19) A los quales diz que ella amonestó:

- Non fagades llanto por mí como muerta, ca soy gozosa en estar asentada con estos en las mesmas sillas (fol. $164 \mathrm{r}^{\mathrm{o}}$ );

(20) Ella llamava en pos de sí al diablo atado, el qual la iva rogando así:

- Señora mía, non quieras, mas si a ti plaze, fazer de mí escarnio, ca non podría de aquí adelante vencer a ninguno (fol. $178 \mathrm{r}^{\circ}$ );

(21) El diablo fuyendo dio bozes: "Ay de mí mesquino, prenderme quiere e atar!» (fol. $\left.178 \mathrm{v}^{\circ}\right)$.

(22) Entonces afirman que el dio bozes en esta guisa: - $\mathrm{OO}$ bienaventurada Magdalena! ¡Confiésome ser vencido!» (fol. 189r ${ }^{\circ}$ ).

(23) E despues aviendo mucho esperado e dando bozes que era burlado, es cierto que oyó vna boz: Aquel que ayer te dixo saludes era tu muger» $\left(\text { fol. } 186 \mathrm{r}^{\circ}\right)^{41}$.

Sólo seis verbos funcionan como verbos de comunicación: escaso repertorio, pero nutrido si lo comparamos con el que ofrecen los libros primero y segundo, donde, si descartamos el que aparece en citas de obras ${ }^{42}$, encontramos muy pocos parlamentos en discurso directo, y en ellos, un reparto de verba dicendi con predominio casi total de decir y presencia anecdótica de responder y fablar:

\begin{tabular}{l|c|c} 
Verbo & Libro Primero & Libro Segundo \\
\hline decir & 16 & 35 \\
fablar & 1 & 0 \\
responder & 2 & 2
\end{tabular}

Respecto a la posición, es indiferente el lugar en que se coloque el verbo, si antes o después del sujeto locutor. También podemos ver en alguna ocasión la intercalación del verbo dicendi, a veces duplicado (25):

41. En un ejemplo paralelo a éste se hace explícito el verbo de decir: «E oyó una boz que dizía: "Aquí estavas, Teodoro, que falsamente te aponían pecado del niño"» (fol. $187 \mathrm{r}^{\circ}$ ).

42. Del tipo «Aristoteles dijo: "No puede ser [...]"》. Los discursos citativos suman veinticinco muestras en el Libro Primero, y en ellas abunda decir, aunque encontramos también comenzar, escribir... Dividimos discurso directo «de personajes» $\mathrm{y}$ «citativo de obras» porque en el discurso directo de personajes se reproduce una situación de comunicación y un discurso, mientras que en el discurso directo citativo se reproduce un discurso y lo que interesa es el contenido, no la situación de comunicación. En este sentido, se acerca más en cuanto a función discursiva al discurso indirecto. 
(24) Lo qual oído, el marido movido por maravilla le dixo:

- ¿Eres biva, amada muger mía?

- Biva - dixo - por cierto, e aun agora llego aquí de mi perenigración donde tú agora buelves (fol. 193ror);

(25) Estando con él ayuntados los discípulos le dixo:

- Maravíllome en que a todos curas con la sola palabra, ¿por qué a Petronila dexas estar trabajada de fiebre?

Sant Pedro dixo:

- Porque así cunple que se faga, mas porque non pienses que la yo non puedo curar ayudándome Dios — dixo - ¡levántate, Petronila, e sírvenos prestamente! (fol. $\left.181 v^{\circ}\right)$.

En (25) la posición intercalada responde muy probablemente a la motivación de deslindar dos actos de habla en la enunciación de san Pedro: uno declarativo a los discípulos, justificativo de la enunciación siguiente (causal de la enunciación lo hago porque así cumple que se faga), y otro perlocutivo, dirigido a Petronila para que se levante. Los dos verbos separan ambos actos, como si cada uno de ellos fijase unas coordenadas de espacio distintas. La deíxis, de hecho, cambia:

$\begin{array}{ll}\text { pienses } & \rightarrow \quad \text { tú, discípulo } \\ \text { levántate } & \rightarrow \quad \text { tú, Petronila (aquí, explícita esa coordenada con un vocativo). }\end{array}$

Esa posición intercalada del dicendi ${ }^{43}$ en medio de un discurso directo no es exclusiva del Libro Tercero, deja nueve muestras en total en toda la obra, en algún caso con una clara función desambiguadora, como en este fragmento de la vida de la romana Avia (Libro Segundo):

(26) E ella queriendo guardar su castidad e onestad como muger notable romana dixo así:

- Ciertamente yo esto non lo faré en alguna manera, ca si el segundo marido fuere bueno segund que ove el primero non quiero yo estar nin bevir con temor de lo poder perder cada día segund que perdí el primero marido que avía, e si acaeciere que este segundo sea malo, pregunto yo - dizía ella - ¿qué nescesidat es después de bueno e virtuoso marido sofrir e sostener mal marido? $\left(\right.$ fol. $\left.83 v^{\circ}\right)$.

Por último, se integran dentro del contexto de reproducción los ejemplos de deíctico catafórico acompañando al verbo de decir. Funcionan como deícticos aditamentos como asi (27) o en esta guisa (28), y también elementos nominales como estas palabras (29):

43. Para Jaime OLIVER ASín (Iniciación al estudio de la historia de la lengua española. Zaragoza: Heraldo de Aragón, 1939, p. 65-73) en los siglos XII y XIII el verbo dicendi aparecía al principio del discurso y en el XIV ya se desplaza al interior; en lo primero, según él, influía la prosa árabe. 
(27) Fincó dello muy maravillada e dixo así al rey Salamón: - Rey, verdadera es la palabra que yo de ti e de tus cosas e de tu sabidoria ove oído (fol. 29r ${ }^{\circ}$; El qual después que por luenga peregrinación se quiso tornar a su tierra e viese sus heredades desiertas dixo así: "Yo non alcançara la sabiduría [...]» (fol. 30ro $)$; e ella queriendo guardar su castidad e onestad como muger notable romana dixo así: - Ciertamente yo esto non lo faré en alguna manera (fol. 83v ${ }^{\circ}$ ); los quales después que fueron dados a sepoltura dizen que el César fabló con Caterina diziendo así:-Virgen generosa [...] (fol. 209r ${ }^{\circ}$ ); e ella llamava en pos de sí al diablo atado, el qual le iva rogando así: — Señora mía... (fol. 178r ${ }^{\circ}$ [...]

(28) Entonces afirman que él dio bozes en esta guisa: — ¡O bienaventurada Margarita! ¡Confiésome ser vencido! (fol. 189rº);

(29) Dio una terrible boz a manera de bestia brava diziendo estas palabras: “ $\mathrm{El}$ coitado de Porfirio [...]» (fol. 210v ${ }^{\circ}$; el enperador fue a ella e le dixo estas palabras: —Con grand maravilla [...] (fol. 207v $\mathrm{v}^{\circ}$; e loando la su castidad dize della el dicho Valerio estas palabras: “ $\mathrm{O}$ famosa e pura castidad! » (fol. $\left.60 \mathrm{v}^{\circ}\right)$; e estando allí dixo estas palabras: - Señor Jesucristo que me criaste [...] (fol. $\left.173 \mathrm{r}^{\circ}\right)$.

En la definición del tipo de relación sintáctica que contraen marco y cita, el empleo de estos deícticos ha sido explicado como un refuerzo de la hipótesis de la relación de yuxtaposición entre ambos componentes (frente a la opinión de que el contenido de la cita es realmente objeto directo del verbo de decir, sustituible por $l o)^{44}$, tal yuxtaposición cuenta frecuentemente en la lengua medieval con un elemento dé́ctico subyacente ${ }^{45}$, aunque en la actualidad los casos de aparición de deíctico son escasos.

3. Caracterizados estos diálogos en cuanto a las condiciones comunicativas que reflejan y descritos sus elementos constituyentes, queda observar las características discursivas de los enunciados que propiamente integran la cita. Como cabía esperar, no se intenta representar deliberadamente en ellos la lengua hablada de su tiempo, con fenómenos sintácticos y léxicos de ese tipo de lengua. Estamos ante diálogos que vienen de una fuente latina, la Legenda aurea, traducida desde el siglo XIV a romance castellano. En esa traducción no se introdujo ninguna novedad estilística respecto al texto de partida, en que no había ningún intento de representar oralidad alguna. La preceptiva literaria y retórica, por otro lado, no consentía que en el discurso escrito se reflejasen determinados niveles lingǘsticos diastráticamente inferiores o diafásicamente coloquiales. Cierto es que

44. Hay un resumen del estado crítico de cada propuesta in: José Luis GIRÓN ALCONCHEL, «El discurso directo como modelo semiótico en la lengua medieval», Investigaciones semióticas, 1, 1986, p. 233-256, p. 244, y también in: E. MÉNDEZ, «Análisis de la reproducción...», p. 112.

45. J. L. GIRÓN ALCONCHEL, ibid., p. 245, pone ejemplos medievales de razón, palabras, esto... aunque señala la escasez de uso de demostrativo (en Virtuosas e claras mugeres inexistente) con esta función. 
esas mismas retóricas sí recomendaban que cada personaje se expresara según su condición ${ }^{46}$, pero esto no se observa en nuestro texto: todas las santas y todos los martirizadores tienen el mismo modo de expresarse. En sus intervenciones verbales no hay elementos diferenciales. Por ser diálogos que se desenvuelven sobre todo en un entorno judicial (interlocutores desconocidos, tema planificado, poca cooperación, es decir, circunstancias poco propicias para que se den rasgos propios de un registro coloquial), ese alejamiento de lo espontáneo no resulta chocante, no se percibe como artificio retórico.

Cierto es que hay algún rasgo lingǘstico exclusivo o fuertemente característico de los parlamentos en estilo directo del Libro Tercero. Tal es el caso del uso de que como subordinante causal tras enunciado imperativo. Desde que con la prosa alfonsí se fijan los modelos discursivos de la escritura romance, se encuentra en la expresión causal una distribución no complementaria de $c a$ y que causal: los textos muestran una preferencia por una u otra conjunción, y la selección de una suele conllevar la ausencia o minoritaria presencia de la otra. Esto sucede en numerosos textos medievales ${ }^{47}$, hasta la desaparición de $c a$, consumada ya a fines del XV. En Virtuosas e claras mugeres, la forma preferida será ca (con 225 ocurrencias, y un nivel de apariciones homogéneo en cada uno de los tres libros de la obra) y la preterida, que, forma causal que ofrece una decena de ejemplos, sobre todo en pasajes dialógicos del Libro Tercero (31), y también en ese mismo libro (32) o en el Libro Primero ll(33) en discursos en estilo directo no dialógicos:

(30) a. ¡Vete de aquí, manjar de muerte, que otro amador me vino antes más claro en nobleza de sangre que tú! (fol. 162ro ${ }^{\circ}$;

b. Padre, perdona, que si mis costunbres e vida te contare... (fol. 179v ${ }^{\circ}$ );

c. Faz lo que te pluguiere, que por cierto aparejada me fallarás para sofrir todos tormentos por Jesucristo (fol. $210 \mathrm{v}^{\circ}$ );

d. Por tanto faz lo que podrás que a mí non podrás engañar (fol. 177 $\mathrm{v}^{\circ}$ );

e. De grandes merescimjentos eres digna, bienaventurada Magdalena, que a mi parir fueste partera (fol. $193 \mathrm{r}^{\circ}$ );

f. A vosotros llamo yo corronpedores de la voluntad, que trabajáis por aconsejar al ánima que desampare a su criador (fol. $\left.175 \mathrm{v}^{\circ}\right)$;

46. Se dice así en la Rhetorica ad Herennium (libro 4, § LII, p. 355-356): «Sermocinatio est, cum aliqui personae sermo atribuitur cum ratione dignitatis». Rhetorica ad Herennium. Vid. Retórica a Herenio, traducción, introducción y notas de J. F. ALcina, Barcelona: Bosch, 1991.

47. En el siglo XIII, obras que «no contaban con una tradición textual y lingüística en romance» seleccionan que en vez de $c a$, mientras que otros textos (los del mester de clerecía o las biblias romanceadas, por ejemplo) escogen $c a$. Vid. Silvia IgLESIAS RECUERO, «Oralidad y escritura en la Edad Media: observaciones sobre la historia de $c a$ y que», Oralia, 3, 2000, p. 277-296, p. 285. 
g. ¡O mesquino, que por mí eres venida en tantos trabajos con tanta virtud e fe e bondad e misericordia! (fol. $113 \mathrm{r}^{\circ}$ );

h. ¡Llevad la maga, llevad la fechizera que trastorna las voluntades e enagena los coraçones! (fol. 164r $\mathrm{r}^{\circ}$;

(31) Estas guardad con linpio e non manzillado cuerpo, que son de paraíso, e por tanto en ningund tienpo nunca se farán marchitas nin dexarán de lançar suave olor (fol. $204 \mathrm{r}^{\mathrm{o}}$ );

(32) Fijo mío, ave piadad de mí que te traxe nueve meses en mi vientre e te di leche tres años e te crié e puse en esta hedad en que al presente eres (fol. $46 \mathrm{r}^{\circ}$ ).

En todos los casos, la causal introducida por que es una causal de la enunciación. Observamos que el empleo de que como subordinante causal está vinculado a enunciados yusivos (ejemplos 30 a-d, 31 y 32) o declarativos (ejemplos 30 e-h). En (30 f) la oración principal expresa, bajo un dictum declarativo, un acto de habla ofensivo, un insulto, y con que se introduce una justificación ${ }^{48}$. La relegación de que en favor de $c a$ en los textos medievales se puede explicar por la diferente marcación que una y otra conjunción tenían. Ambas se utilizaban en un mismo ámbito: la justificación enunciativa, pero desde mediados del XIII, ca se distinguía por ser un mecanismo de conexión propio de la lengua escrita, o de una lengua oral culta y formal, en tanto que que pertenecería a niveles menos formales de escritura, y sería más distintivo del coloquio y la lengua oral. Por ello se documenta más en los textos medievales que presentan pasajes dialogales, o llamadas intratextuales a un receptor, siempre que en ese texto no haya una decidida voluntad de alejamiento de los mecanismos expresivos de la lengua hablada. Obsérvese que en la obra de don Álvaro, nueve de los diez ejemplos arriba transcritos de que causal pertenecen a los fragmentos dialogales de vidas de santas, pero aun en tales entornos, es preferido $c a$ a que:

(33) a. Non fagades llanto por mí como muerta, ca soy gozosa en estar asentada con estos en las mesmas sillas (fol. $164 \mathrm{r}^{\circ}$ );

b. Cata non lo fagas, $c a$ traes los sacramentos del Señor e resplandesces por dignidad de sacerdocio (fol. $180 \mathrm{v}^{\circ}$ );

c. Toma vianda, $c a$ yo soy Cristo a quien sienpre amaste (fol. $\left.199 \mathrm{v}^{\circ}\right)$;

d. Aconsejo e ruégote que non cures de nos responder con dubdas, $c a$ te non cobdiciamos aver por sierva mas serás nuestra muger (fol. 209vº); e. Non ayas pavor, reina amada de Dios, $c a$ oy alcançarás por reino en lugar del reino que muy aína ha de perescer el reino eternal $\left(\right.$ fol. $\left.210 \mathrm{r}^{\circ}-\mathrm{v}^{\circ}\right) \ldots$

48. Con esta clase de actos de habla, en español actual la justificación enunciativa se introduce mayoritariamente con que (vid. Salvador GUTIÉRREZ ORDÓÑEZ, «Causales», Boletín de la Real Academia Española, 63, 2000, p. 47-159, p. 126). 
También un uso de pues en uno de los diálogos de este Libro Tercero podría adscribirse al plano de la inmediatez comunicativa. Nos referimos a este ejemplo:

(34) Pasqual dixo:

- Cesarán las palabras quando viniéremos a las feridas.

Lucía dixo:

—Cree tú que las palabras de Dios inmortal non se pueden esconder.

Pasqual dixo:

-Pues, ¿el Espíritu Santo es en ti e tu de Dios eres?

Lucía dixo:

- Confieso que soy sierva de Dios, e los que casta e santamente biven templo del Espíritu Santo son (fol. 175vº .

En este diálogo, pues introduce una relación con lo recién dicho; tiene un sentido consecutivo: el emisor avisa mediante pues de que ha extraído cierta consecuencia de la intervención previa y pregunta por la validez de esa conclusión, no se compromete con la verdad de esa conclusión hasta que no le quede confirmada por el interlocutor. Este ejemplo es el único que hemos localizado en Virtuosas e claras mugeres de pues en réplica. Según Iglesias ${ }^{49}$, aunque se puedan subdividir empleos diversos de pues en contexto dialogal, el uso de pues en diálogos parece reflejo real de los diálogos orales de la época: desde los textos del XIII, pues es frecuente en diálogos, y en el Corbacho, por ejemplo, aparece profusamente en tales entornos. Pero, si ese pues puede estar dejando filtrar un rasgo de lo hablado de la época, se dan al mismo tiempo, al igual que hemos visto con la alternancia de que/ $c a$, usos que en absoluto pueden adscribirse a ese dominio, por ejemplo en (36) hay un uso de pues con significado consecutivo (equivalente a por tanto, asi pues, así que, aunque también puede asignársele valor de estructurador de la información) no reforzado por ningún elemento, es decir, con los parámetros de empleo que tenía esta forma en fecha anterior al siglo XV, un pues existente en la propia fuente, que nos está remitiendo a un estadio lingüístico no estrictamente coincidente con la fecha de escritura de la obra:

(35) Mas yo curaré de guardar la ley de Dios: tú has temor de los príncipes del mundo, yo temo a Dios inmortal; tú te guardas de los enojar, yo trabajo de me desviar de ofender a Dios; tú piensas cómo fazerles cosa agradable, yo cobdicio sobre todas cosas a plazer a Jesucristo. Pues faz tú lo que entiendas que es tu pro, ca yo faré lo que entendiere que es provecho mío (fol. 175r ${ }^{\circ}$ ).

49. Silvia IGLESIAS RECUERO, «La evolución histórica de pues como marcador discursivo hasta el siglo XV», Boletín de la Real Academia española, 80, 2000, p. 209-305, p. 269. 
En definitiva, los diálogos que han conformado nuestra base de análisis presentan una recreación notablemente estilizada de escenas que mimetizan interacciones comunicativas en un canal oral, y sólo algún rasgo aislado puede adscribirse al dominio de la inmediatez.

En el plano de análisis de la cita propiamente dicha, del enunciado dialógico en sí, es cuestión de relevancia el tipo de acto de habla que se representa y la plasmación lingüística que esos actos de habla seleccionan. Dentro de estos macroactos de habla que son los interrogatorios a las santas, tienen presencia dominante los pares pregunta - respuesta. En un par dialógico, la presencia de una pregunta en una intervención (habitualmente, acaparando la intervención iniciativa del intercambio) tiene la facultad de subordinar el intercambio verbal a esa pregunt ${ }^{50}$. En nuestros interrogatorios, las peticiones de información suelen escoger la forma enunciativa de las preguntas ${ }^{51}$. Es lo más frecuente que esas interrogativas sean no marcada ${ }^{52}$, meras preguntas que piden información. Pero también hay muestras de interrogaciones marcadas, esto es, que presentan indicadores orientativos de su interpretación, tales como términos polares negativos o estructuras ecoicas o reflejas:

(36) El adelantado dixo:

- ¿Non sabes, desaventurada, que me es dado poderío de dar la vida? (fol. $\left.205 \mathrm{v}^{\mathrm{o}}\right)$.

(37) Entonces Quinciniano encendido en saña la mandó atormentar la teta, e, ella bien atormentada, que gela cortasen. Ágata le dixo:

- $\mathrm{O}$ cruel e vano tirano!, ¿non eres confuso de verguença en cortar a la fembra lo que tú, llegado a los pechos de tu madre, muchas vezes mamaste con la boca? E yo enteras tengo mis tetas con que crío mis sentidos desde la niñez consagradas a Dios inmortal (fol. $\left.171 \mathrm{v}^{\circ}-172 \mathrm{r}^{\circ}\right)$.

50. Con el término de «pregunta» aludimos a un tipo de acto de acto de habla con unas características fijas: un acto directivo de carácter interaccional e instativo, en el que ha de cumplirse la condición de sinceridad señalada por Searle JJohn SEARLE, Actos de habla. Ensayo de filosofia del lenguaje, Madrid: Cátedra, 1986, p. 74, traducción de Speech acts: an essay in the philosophy of language, 1969). Ante la pregunta, el interlocutor debe responder para satisfacer el enigma que el hablante le plantea. Ese enigma puede ser planteado por muy distintos procedimientos lingüísticos. Son preguntas tanto ¿A qué hora empieza el concierto? como Dime a qué hora empieza el concierto, es decir, como acto de habla, la pregunta puede estar expresada por enunciados de diverso tipo. Igualmente, la interrogación (¿A qué hora empieza el concierto?) puede expresar, entre otros, el valor ilocutivo de pregunta.

51. Había imperativo retórico también para esta clase de escenas: la retórica clásica codificaba las formas en que debía establecerse «la interrogatio», al juego de preguntas y respuestas se le daba el nombre de percontatio (vid. H. LAUSBERG, op. cit., § 354).

52. $\mathrm{M}^{\mathrm{a}}$ Victoria ESCANDELL, «Los enunciados interrogativos. Aspectos semánticos y pragmáticos», in: BosQue-Demonte (dir.), Gramática descriptiva de la lengua española, Madrid: Espasa Calpe, 1999, p. 3929-3991. 
Ese non es un índice modal que expresa en ambos casos la actitud de desacuerdo del emisor ante una situación que contradice sus expectativas, por ejemplo en ¿inon sabes que...?, en ese caso con non se niega la aceptación de la predicación que sigue.

Resulta incomprobable la catalogación como construcciones - $\mathrm{eco}^{53}$ de algunas de las interrogaciones presentes en estos diálogos:

(38) E dende pasados quatro días Quinciniano le dixo:- O adora a los dioses o si por ventura non quisieres padescerás mas graves tormentos.

Ágata respondió:

Cuitado, tus palabras son locas e malas, e nin te veo seso nin entendimiento. ¿Por qué manera quieres que adore a las piedras e dexe a Dios del cielo que me crio?

Quinciniano dixo:

¿Quién te crio?

Agata respondió:

Cristo fijo de Dios (fol. 172vo $\mathrm{v}^{\circ}$.

(39) Respondió Lucía:

- Mi patrimonio yo lo puse en lugar seguro, e corronpedores de cuerpo nin de voluntad nunca los conoscí.

Pasqual dixo:

¿ ¿Quáles dizes tú que son los corronpedores del cuerpo e de la voluntad?

Lucía dixo:

(fol. $\left.175 \mathrm{r}^{\circ}-\mathrm{v}^{\mathrm{o}}\right)$.

En casos donde la colocación del elemento interrogativo no está desplazada al final, _ ¿Has visto a Luis dónde?, ejemplo que claramente se podría calificar como pregunta eco- - sólo la entonación diferencia a la interrogativa eco de una interrogativa normal. En los ejemplos (38) y (39), con sintaxis interna de interrogativa estándar, se cumplen algunas de las propiedades de las preguntas - eco, pero otras de las propiedades de esta construcción son incomprobables. Por no poderse recuperar la entonación original, no sabemos si estamos ante el patrón entonativo descendente propio de las interrogativas parciales o hay otras cadencias. Hay en esos ejemplos, efectivamente, una citación retrospectiva de lo emitido por el otro hablante. El quién te crió de (38) puede interpretarse como una interrogativa ecoica especifi-

53. Una de las constantes gramaticales en la organización y formulación de los mensajes en el registro coloquial conversacional es la presencia de construcciones - eco, uno de los mecanismos de redundancia que se dan en la sintaxis no convencional del español conversacional. Las construcciones - eco pueden presentarse como turnos repetitivos que consolidan la ilocución. Para Dumitrescu, la interrogación ecoica es aquella «estructura sintáctica interrogativa que repita en parte o en su totalidad un segmento del discurso precedente que le sirva de estímulo» (vid. Domnita DUMITRESCU, «Función pragma-discursiva de la interrogación ecoica usada como respuesta en español», in: Henk HAVERKATE et al. (ed.) Aproximaciones pragmalingüísticas al español, Amsterdam: Rodopi - Diálogos hispánicos, 12, 1993, p. 51-85, p. 52. 
cativa o explicativa, se solicita al interlocutor que aclare y repita una parte de su enunciado previo, aquí por ser una idea que justifica el martirio: la defensa de que Dios es el padre. Con quáles en (39) se solicita una precisión de un concepto vago referencialmente. Son intervenciones reactivas, de protesta y sorpresa. El constituyente interrogativo eco es el inicial (CUÁL, QUiÉN) que debe de estar dotado de un acento prosódico fuerte para que se ligue anafóricamente a lo recién dicho. De esta forma se restituye "el status [sic] de información nueva (o sea, de foco informativo) a un constituyente erróneamente asumido por el interlocutor como información compartida por ambos participantes $»^{54}$.

Tras las preguntas de los martirizadores, llegan las respuestas de las santas. Los enunciados que adquieren el valor discursivo de respuesta son en el libro tercero de Virtuosas e claras mugeres actos ilocutivos de todo tipo. Ya hemos visto que no hay ningún interés cooperativo de las santas con sus martirizadores, pero en todos los casos sus preguntas y sus amenazas son contestadas. A veces son contestadas con respuestas que efectivamente satisfacen la petición de información pero otras veces no estamos ante respuestas sino ante réplicas ${ }^{55}$. Así, en la vida de santa Cecilia, la santa arguye al martirizador con tres réplicas: una que cuestiona la propia aptitud de la interrogativa como pregunta; otra que niega la presuposición en que se funda la interrogación, y una tercera que niega la información y rechaza la expectativa contenidas en las pregunta:

(40) Escriven que el malvado onbre Almaquio mandó llamar a Secilia e le preguntó de qué condicion era. Secilia respondió:

- Por cierto yo soy noble de linage.

El adelantado dixo:

-De la religion te pregunto.

Secilia dixo:

- Esta pregunta tiene el comienço desvariado porque paresce conprehender dos respuestas.

$[\ldots]$

Entonces el adelantado movido con ira dixo:

- ¿Por qué fablas así tan soberviamente?

Sicilia respondió:

- Non fablo sobervio como piensas, mas firme

$[\ldots]$

El adelantado dixo:

- ¿Non sabes, desaventurada, que me es dado poderío de dar la vida?

54. D. Dumitrescu, ibid., p. 63.

55. Llamamos así (a partir de «L'acte de question et l'acte d'assertion:opposition discrète ou continuum», in: Catherine KERBRAT-ORECCHIONI [ed.], La question, Lyon: Université Lyon II, 1991, p. 109-123) a las intervenciones reactivas a una pregunta que no tratan de proporcionar información al que pregunta sino que cuestionan la pertinencia del enunciado interrogativo, el presupuesto pragmático o topos en que se apoya o su adecuación al contexto. 
Sicilia le respondió:

-Quiero provar que mentiste agora contra verdad, ca puedes quitar la vida a los que biven, mas darla a los muertos non puedes. Pues, si bien acatares, eres fazedor de muerte e non de vida (fol. $205 \mathrm{v}^{\circ}$ ).

4. Nuestro estudio ha explorado los mecanismos de construcción lingüística que subyacen a los diálogos de Virtuosas e claras mugeres, a partir del inventario, descripción y caracterización de sus elementos constituyentes, pertenezcan al nivel del enunciado o al de la enunciación de ese discurso referido. Una vez más, se muestra que la gramática formal no puede ser suficiente para describir los elementos de un acto comunicativo, y que es necesario para explicar exhaustivamente los rasgos lingüísticos de un texto tener en cuenta factores como sus condiciones de enunciación, la intención del acto comunicativo, la tradición discursiva, las restricciones de género, las condiciones de informatividad y coherencia... El análisis de la ficcionalización de lo medialmente oral en las escenas dialógicas de este libro sufre la limitación de base de estar interferido por la intención notablemente estilizadora del autor, pero, con todo, ofrece resultados de interés en asuntos como la expresión del modus, la distribución y señalamiento de la toma de turnos, los tipos de verbos introductores empleados y sus implicaciones... Nuestra intención ha sido mostrar algunas de las características lingǘsticas de un pequeño corpus de diálogos cuatrocentistas. Esperemos que sucesivos análisis permitan contar con conclusiones más amplias. 